\title{
Skeletal injuries following unintentional fall from height
}

\author{
Kaza ile yüksekten düşme sonucu oluşan iskelet yaralanmaları
}

\author{
Divesh GULATI, Aditya Nath AGGARWAL, Sudhir KUMAR, Anil AGARWAL
}

\section{BACKGROUND}

Falls from height are one of the leading causes of death from unintentional injuries.

\section{METHODS}

We reviewed cases of musculoskeletal trauma due to fall from height, who were treated at a tertiary care hospital in Delhi over a one-year period, with respect to demographic data, site of accident, circumstances and location of fall, approximate height of fall, season, landing surface, details of skeletal and other injuries, and duration of hospital stay.

\section{RESULTS}

Of 1451 admissions during the period, 138 were injured due to fall from height. Thirty-seven cases were excluded. The mean age of the patients was 31.3 years. The mean height of the fall was 4.54 meters (range: 0.6-12 meters). A total of 126 fractures occurred in 101 patients: 55 in the upper limbs, 50 in the lower limbs, 14 in the spine, and 7 in the pelvis. Associated injuries included head $(n=17)$, chest $(n=9)$ and abdominal injuries $(n=6)$. Ninety patients $(89 \%)$ needed surgical intervention for fracture management. Eleven (10.8\%) of these 101 injuries were fatal.

\section{CONCLUSION}

Fall from height is a potentially preventable cause of skeletal injuries, as most of the injuries sustained due to fall from height were domestic injuries and occurred due to poor dwelling units.

Key Words: Fall from height; skeletal injury; injury pattern; unintentional fall; dwelling units.
$\boldsymbol{A M} \boldsymbol{A C}$

Kazayla yüksekten düşme yaralanmaları önde gelen ölüm nedenlerinden biridir.

\section{GEREC VE YÖNTEM}

Bir yıl boyunca Delhi'de 3. basamak bir hastanede, yüksekten düşmeye bağlı kas-iskelet travmalı olguların, demografik veri, kaza yeri, düşmeye ilişkin koşullar ve lokasyon, yaklaşık düşme yüksekliği, mevsim, düşme alanı yüzeyi, iskelet yaralanmaları ile diğer yaralanmaların ayrıntıları ve hastanede kalma süresi değerlendirildi.

\section{BULGULAR}

Hastaneye yatırılan 1451 olgunun 138'i yüksekten düşme nedeniyle yaralanmıştı. Bu olguların 37'si çalışma dışında bırakıldı. Hastaların ortalama yaşı 31,3 yıldı. Düşmelerin ortalama yüksekliği 4,54 m idi (dağılım, 0,6-12 m) idi. Elli beşi üst, 50'si alt ekstremitelerde, 14'ü omurga ve 7'si pelviste olmak üzere, 101 hastada toplam 126 kırık oluşmuştu. Eşlik eden yaralanmalar, baş $(n=17)$, göğüs $(n=9)$ ve karın bölgesi yaralanmalarını $(n=6)$ içeriyordu. Doksan hastada (\%89), kırık tedavisi için cerrahi girişim uygulandı, 101 yaralanmanın 11 'i $(\% 10,8)$, ölümle sonuçlandı.

\section{SONUÇ}

Yüksekten düşmeye bağlı uzun süreli yaralanmaların çoğunun evle ilgili yaralanmalar olması ve kötü konut birimlerine bağlı olarak gerçekleşmesi nedeniyle, yüksekten düşme, potansiyel olarak önlenebilir bir iskelet yaralanması nedenidir.

Anahtar Sözcükler: Yüksekten düşme; iskelet yaralanması; yaralanma paterni; kazayla düşme; konut birimleri. 
Falls from height are one of the leading causes of death from unintentional injuries, ${ }^{[1-3]}$ which disproportionately affect the very young and the very old. Falls from height are the most common cause of non-fatal childhood injuries but are often fatal in the elderly. ${ }^{[4,5]}$

Typically, fall from height has been associated with multi-storey low income housing in urban areas, ${ }^{[1-3]}$ but falls have also been reported in those areas where people sleep on the roofs of single- or double-storey buildings. Other factors like unsafe/improper staircases, uneven surfaces, poor lighting, and slippery surfaces may contribute to a fall. ${ }^{[2]}$ In the elderly, diminished eyesight and problems with gait and balance may result in a fall.

While fall as a cause of injury is extensively documented and reported in the literature from the west, ${ }^{[1-5]}$ very limited data are available in our country about the morbidity and mortality due to musculoskeletal injuries following falls from heights.

In this study, we retrospectively evaluated the demographic data, mortality rates, causes of fall, and injury pattern after fall from heights to facilitate the identification of various patterns and to utilize the information for formulating the necessary preventive measures.

\section{MATERIALS AND METHODS}

We retrospectively reviewed cases of musculoskeletal trauma as a result of fall from height (more than standing height) ${ }^{[2,3]}$ over one year (May 2009 to April 2010) at a tertiary care hospital in Delhi. Patients who sustained musculoskeletal injury due to fall from height and were admitted in the Orthopedic Department for observation/intervention were included in the study. The trauma records of the orthopedic emergency room were reviewed to ascertain patient details, and the case notes from the Medical Records Department were accessed subsequently. Patients who tripped or slipped while walking and those for whom record of the height and circumstances of the fall were not available in the case record were excluded. Also excluded from the study were: patients who were not admitted but were sent from an orthopedic casualty department after primary management, falls that were a result of suicide attempts or homicide (intentional injuries may have different patterns of fall and sustained injury), and cases brought after death.

The authors (SK, ANA) studied all available records and documented the age and sex of the patient, site of accident, circumstances and location of the fall, approximate height of the fall, season, landing surface, details of musculoskeletal and other injuries, and duration of hospital stay. The patients were divided into four groups according to age: children ( $0-10$ years), adolescents/young adults (11-20 years), adults constituting the productive age group (21-60 years), and elderly ( $>60$ years).

All fractures were tabulated as injuries to upper limbs, lower limbs, spine, and pelvis in each age group with confidence intervals (Cis). The number of fractures sustained to upper and lower limbs, the spine and pelvis were compared between children, adolescents, adults, and the elderly for any significant differences.

Chi-square or Fisher's exact test was used to compare the proportion of each type of fracture among the four groups. The Statistical Package for the Social Sciences (SPSS) version 13.0 statistical program was used for analysis, and a $p$ value less than 0.05 was considered as significant.

\section{RESULTS}

The number of patients seeking treatment in orthopedic emergency during the period of the study was 21,458 , of which 1451 patients were admitted. Out of the 1451 cases, $138(9.5 \%)$ were injured due to fall from height.

Nineteen cases of intentional injuries (suicides $[\mathrm{n}=11]$, homicides $[\mathrm{n}=8]$ ) and 18 cases for whom the height and circumstances of the fall could not be ascertained were excluded, leaving 101 cases to constitute the present study.

Seventy-three were males and 28 females, and the mean age of patients was 31.3 years (range: 2 months - 85 years). There were 19 children, 20 adolescents/ young adults, 49 adults, and 13 elderly patients (Fig. 1).

The mean height of the fall was 4.54 meters (range: $0.6-12$ meters). The majority of patients ( $\mathrm{n}=61,60.4 \%)$ sustained an injury due to fall from a height of $>3$ meters (Table 1 ). The falls most commonly occurred from rooftops $(\mathrm{n}=52,51.4 \%)$, wooden ladders $(\mathrm{n}=21$, $20.8 \%)$, trees $(n=12,11.8 \%)$, windows $(n=7,6.9 \%)$, construction sites $(n=6,5.9 \%)$, and electricity poles

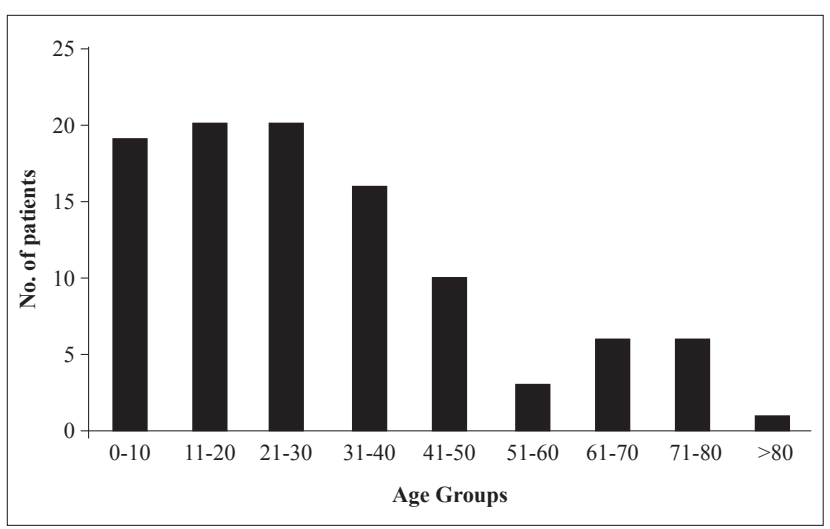

Fig. 1. Bar diagram showing the age distribution of patients in the study. 
Table 1. Distribution of patients as per height of fall

\begin{tabular}{lc}
\hline Height of fall (meters) & No. of patients \\
\hline$<1.5$ meters & $8(7.9 \%)$ \\
$1.5-3$ meters & $32(31.6 \%)$ \\
$3-6$ meters & $24(23.7 \%)$ \\
$>6$ meters & $37(36.6 \%)$ \\
\hline
\end{tabular}

Table 2. Time of fall

\begin{tabular}{lc}
\hline Time of fall & No. of patients \\
\hline 6:00 a.m. till 12:00 noon & $23(22.7 \%)$ \\
12:00 noon till 6:00 p.m. & $25(24.7 \%)$ \\
6 p.m. till 12:00 midnight & $19(18.8 \%)$ \\
12:00 midnight to 6 a.m. & $34(33.6 \%)$ \\
\hline
\end{tabular}

$(n=3,2.9 \%)$. The landing surface consisted mainly of concrete $(n=63,62.3 \%)$, ground $(n=28,27.7 \%)$ and wooden decks $(n=10,9.9 \%)$.

The majority of falls occurred in summer and monsoon months in India between April and August, accounting for $90 \%(n=91)$ of all cases. Increased falls in children were noted in the months of July and August, and most of these falls occurred while children were flying kites from rooftops (10 of 19 children). Another increase in the number of pediatric cases was observed in the months of April and May, when children fell accidentally from trees while trying to pick fruit ( 7 of 19 children). The largest number of falls (Table 2) took place between 12:00 p.m. midnight and 6:00 a.m. (34 patients, $33.6 \%$ ), but there was no significant difference between the number of falls at the different time intervals ( $p>0.05$ ). Most patients (26 of 34 patients) who fell during this time period gave a history of fall while going to urinate late at night or in the early morning in a state of decreased attention.

A total of 126 fractures occurred in 101 patients (Tables 3, 4). Nineteen patients $(18.8 \%)$ had more than one fracture. The fracture rate (number of fractures sustained per individual) was 1.20 in children and adolescents, 1.28 in adults and 1.23 in the elderly. Though the fracture rate per patient was highest in adults, the difference when compared with other age groups was not significant ( $\mathrm{p}>0.05)$. Of the 126 fractures, 55 (43.6\%, CI: 34.9-52.2\%) were in the upper
Table 3. Fracture distribution

\begin{tabular}{llc}
\hline Region & Fracture and Dislocation & Number \\
\hline Upper limb & Radial and ulnar shaft fractures & 15 \\
& Distal end radius fractures & 11 \\
& Supracondylar fracture, humerus & 9 \\
& Intercondylar fracture, humerus & 5 \\
& Shoulder dislocation & 5 \\
& Radial head/neck fractures & 4 \\
& Lateral condyle fracture, humerus & 4 \\
& Metacarpal fractures & 2 \\
& Total & $\mathbf{5 5}$ \\
Lower limb & Intertrochanteric/subtrochanteric & \\
& fracture, femur & 14 \\
& Tibia and fibula & 14 \\
& Calcaneum & 11 \\
& Femur shaft & 6 \\
Pelvis & Intra-capsular fracture, femur neck & 4 \\
& Hip dislocation & 1 \\
& Total & $\mathbf{5 0}$ \\
& Cervical & 2 \\
& Thoracolumbar & 12 \\
& Total fracture & 14 \\
& & 7 \\
& &
\end{tabular}

limbs, $50(39.6 \%$, CI: $31.1 \%-48.1 \%)$ in the lower limbs, 14 (11.1\%, CI: 5.6\%-16.6\%) in the spine and 7 (5.5\%, CI: $1.5 \%-9.5 \%)$ in the pelvis. Radial and ulnar shaft fractures $(11.9 \%)$ and distal end radius fractures $(8.7 \%)$ were the most commonly sustained fractures in the upper limb. More than $50 \%$ of fractures in children $(12 / 23)$ were upper limb fractures. In the lower limb, pertrochanteric fractures $(14.2 \%)$, and fractures of the tibia and fibula (11.1\%) and calcaneum (8.7\%) were the most common.

Two patients had cervical fracture dislocations (C5-C6 fracture dislocation, C3-C4 subluxation), and 12 patients had dorsolumbar junction injuries ( 3 patients with D1 2 burst fracture, 6 with L1 burst fracture and 3 with L1-L2 fracture dislocation). No fractures of the vertebral column were seen in the children or adolescent age groups, while 13 adults (26\%) had spinal injuries, and the difference was statistically significant ( $p=0.034$ and 0.032 , respectively). Seven patients suffered from a pelvic fracture, which were open book type in 5 cases and vertically displaced in 2; all were

Table 4. Number of fractures sustained in each age group (note that 19 patients had more than one fracture)

\begin{tabular}{|c|c|c|c|c|c|}
\hline Fractures & Children (19) & Adolescents (20) & Adults (49) & Elderly (13) & Total \\
\hline Upper limb & 12 & 10 & 26 & 7 & 55 \\
\hline Lower limb & 10 & 13 & 20 & 7 & 50 \\
\hline Spine & 0 & 0 & 13 & 1 & 14 \\
\hline Pelvis & 1 & 1 & 4 & 1 & 7 \\
\hline Total & 23 & 24 & 63 & 16 & \\
\hline
\end{tabular}


stabilized by external pelvic fixator. Four of these seven patients eventually died. There was no statistically significant difference in the distribution of other fractures (except spine) among the various age groups $(\mathrm{p}>0.05)$.

Fourteen fractures $(11.1 \%)$ were open injuries (fractures of tibiae and fibulae $[\mathrm{n}=6]$, pelvic fractures $[\mathrm{n}=2]$, femur $[\mathrm{n}=1]$, humeri $[\mathrm{n}=3]$, radial and ulnar shafts $[\mathrm{n}=1]$ and metacarpal $[\mathrm{n}=1])$. Vascular injury was found in four patients (open supracondylar fractures of humerus with lacerated brachial artery [n=2], open grade IIIc fracture of tibia and fibula $[\mathrm{n}=1]$ and proximal tibial fracture with compartment syndrome $[n=1])$. The patient with open fracture of the tibia and fibula with vascular injury eventually required an amputation. The limbs survived in the other three patients. Eleven patients with spinal column injuries had associated neural deficits (1 patient had complete quadriplegia below $\mathrm{C} 5,3$ patients had complete paraplegia below D12 and 7 had paraparesis). Six patients with limb injuries also had injury to peripheral nerves (sciatic nerve following hip dislocation $[n=1]$, tibial nerve following fracture of leg bones $[n=1]$, ulnar nerves following intercondylar fracture of humerus $[\mathrm{n}=2]$, posterior interosseous nerve due to radial neck fracture $[n=1]$, and axillary nerve following shoulder dislocation $[\mathrm{n}=1]$.

Associated injuries to other systems were found in 21 patients $(20.7 \%)$. These included 17 head injuries (concussions [ $\mathrm{n}=6]$, subarachnoid hemorrhages $[\mathrm{n}=5]$, subdural hemorrhages $[\mathrm{n}=4]$ and extradural hematoma $[\mathrm{n}=2] ; 11$ had skull fractures [4 of whom underwent craniotomies]), nine chest injuries (hemopneumothorax with associated rib fractures) and six abdominal injuries (splenic lacerations [ $\mathrm{n}=3$ ], liver lacerations $[\mathrm{n}=2]$ and renal laceration $[\mathrm{n}=1])$. Eighty-one surgeries were conducted for orthopedic fracture management. The average duration of hospital stay was 4.1 days (range: 1-82 days).

There were 11 deaths $(10.8 \%)$ in the 101 patients studied. The adult age group had the highest fatality rate ( 6 of 11 deaths, $54.5 \%$ ); the children and adolescent age groups had two fatalities each, and one of 13 elderly patients died. The difference in fatality rates between these groups was not significant $(p=1.00)$. Four patients died of pelvic injuries, of which two were open fractures. Five patients died of head injury. The cause of death in the other two was an injury to the abdominal viscera.

\section{DISCUSSION}

Falls from heights are the most frequent cause of injuries requiring hospitalization in the western population. ${ }^{[6,7]}$ It is a common mode of trauma in the lessdeveloped countries as well, but the injuries often are not documented. There is insufficient data in the literature in our country establishing the range of musculoskeletal injuries due to fall from heights. ${ }^{[8]}$ Most of the unintentional falls from height may be preventable by simple measures, which may help to decrease the burden on the healthcare system in addition to decreasing the morbidity and mortality of the population. However, the number and patterns of falls need to be studied first to ascertain the specific corrective action that is needed.

The above series of 101 cases were collected over a period of one year from the trauma registry of the emergency room of a tertiary care hospital in Delhi, India. The hospital caters predominantly to a residential area population of low-middle socioeconomic level. Skeletal injuries following fall from height constituted $9.5 \%$ of the orthopedic emergency admissions in this hospital. The admission rate in various studies ranges from $6-42 \%,{ }^{[9]}$ with our admission rate being on the lower side. This might be explained by the fact that only those patients admitted to orthopedic emergency that required specialized orthopedic care were included in the study. This does not reflect the true admission rate from injuries due to fall from height at our center, as we did not consider patients who did not seek orthopedic treatment.

The male preponderance $(72.2 \%)$ was consistent with other studies. ${ }^{[2,5]}$ The peak age of fall was seen between 11 and 30 years, and almost $75 \%$ of patients were in their first four decades. Musculoskeletal injuries to this age group have the propensity to lead to disability, affecting the most productive section of society in addition to being a burden on the healthcare resources.

The majority of the injuries $(90 \%, n=91)$ were sustained in households and only $10 \%$ at places of work. This appears to be a result of increased focus at ensuring workman safety in industrial establishments. Households too need to be brought under stringent safety regulations. The majority of falls occurred from rooftops $(n=52,51.4 \%)$ in summer months, and maximum falls were between 12:00 p.m. midnight and 6:00 a.m. $(\mathrm{n}=34,33.4 \%)$. The most common presentation (26 of 34 patients) was a fall sustained while going to urinate late at night or in the early morning in a state of decreased attention. A similar phenomenon was also observed by Goren et al. ${ }^{[10]}$ in Turkey, where similar climatic conditions exist. July and August are "kite flying months", especially in the northern part of India. Children usually fly kites from rooftops of lowmiddle income group urban dwellings. An increase in the number of falls from height, especially in children, was observed in these months. Another peak in pediatric injuries was observed in the months of April and May. Indian blackberry trees (Syzygium cumini), 
called 'Jamun' in India, bear fruit during these months and children climb these trees to pick the fruits, exposing them to accidental fall from height. Twenty-one percent of patients sustained trauma due to fall from wooden ladders. Wooden ladders are common in low income households where people cannot afford cemented staircases due to lack of space. These often are not strong enough and give way, leading to falls.

The Committee on Injury and Poison Prevention reported radius, ulna and femur as the most frequent sites of fracture in pediatric falls in the United States. [11] Our findings matched their observations, but we also found high rates of hip injuries (14.2\%) and fractures of the tibiae and fibulae (11.1\%) in our study. Our observations, that fractures of the spine, pelvis and calcaneum are less common in children than among adults, is similar to their findings. The number of adult patients ( $>20$ years) sustaining fracture of the calcaneum was relatively small in the present series $(n=11)$. However, this data may be skewed because most of these fractures of the calcaneum were not admitted, except for those who had a severe soft tissue injury, open fractures, or concomitant fractures requiring surgery or required surgical fixation.

Lapostolle et al. ${ }^{[12]}$ performed a multivariate analysis of 287 patients who sustained injury due to fall from height and inferred that age, height of fall, nature of impact surface, and the body part first hitting the ground were the independent prognostic factors in victims of fall from height. It has been observed that children, due to their larger head to body ratio, are more susceptible to head injuries, whereas adults are more prone to limb injuries. ${ }^{[12,13]}$ Agalar et al. ${ }^{[14]}$ concluded that height of fall and age were significant factors in determining the severity of trauma. However, Goodacre et al. ${ }^{[15]}$ opined that height of fall is a poor predictor of major injury. We could not comment on the relation between height of fall and severity of injury in our study as trauma scores were not mentioned in the available case records. Previous studies have reported little mortality due to fall from heights. ${ }^{[16,17]}$ There were 11 deaths (10.8\%) in our study. A similar death rate was reported in a study in Australia by Kent et al., ${ }^{[18]}$ but the study had a high proportion of people above age 60 . The elderly age group formed only $13 \%$ of our patients, and there was only one fatality in this age group. The death rate does not represent the true mortality rate in this study following fall from height, as we excluded patients who were brought to the hospital after death, and there might have been patients who died immediately after fall who were not brought to the hospital.

A study of patterns of fatal falls was conducted in our institution on patients brought post-mortem by Kohli et al., ${ }^{[8]}$ and injuries to the head $(75.5 \%)$ were found to be the major cause of mortality. In our study, head injury led to death in five patients $(45.4 \%)$, whereas pelvic fractures led to four fatalities $(36.3 \%)$. Previous studies specifically commented on the absence of abdominal trauma due to falls, ${ }^{[19,20]}$ but we found eight major abdominal injuries due to fall from height, with two fatalities. We also found absence of vertebral column fractures in children and adolescents, while 13 adults had spinal injuries. This finding was consistent with other studies, ${ }^{[12,13,18]}$ and may be due to the greater flexibility in a child's spine or because of the larger head to body ratio.

The study has its limitations, as the height of fall was considered as told by the patient or attendant in the case record. No site visits were conducted to determine the exact height of the fall. The exact number of cases of head injury, abdominal trauma and other system involvement due to fall from height could not be determined as these cases were not necessarily admitted to an orthopedic ward. Possible predictors of injury severity could not be ascertained as trauma scores were not calculated or mentioned in the available case records.

In conclusion, this is a pilot study from a single center to gauge the range of skeletal injuries following fall from height using the hospital trauma registry. Most of the injuries following fall from height were found to be domestic in nature owing to poor dwelling units. These injuries are potentially preventable by simple legislative measures and public awareness.

\section{REFERENCES}

1. Sieben RL, Leavitt JD, French JH. Falls as childhood accidents: an increasing urban risk. Pediatrics 1971;47:886-92.

2. Garrettson LK, Gallagher SS. Falls in children and youth. Pediatr Clin North Am 1985;32:153-62.

3. Spiegel CN, Lindaman FC. Children can't fly: a program to prevent childhood morbidity and mortality from window falls. Am J Public Health 1977;67:1143-7. CrossRef

4. Baker SP, O’Neill B, Ginsburg MJ, Li G. The injury fact book. 2nd ed. New York, NY: Oxford University Press; 1992.

5. Mosenthal AC, Livingston DH, Elcavage J, Merritt S, Stucker S. Falls: epidemiology and strategies for prevention. J Trauma 1995;38:753-6. CrossRef

6. Allshouse MJ, Rouse T, Eichelberger MR. Childhood injury: a current perspective. Pediatr Emerg Care 1993;9:159-64.

7. Rivara FP, Calonge N, Thompson RS. Population-based study of unintentional injury incidence and impact during childhood. Am J Public Health 1989;79:990-4. CrossRef

8. Kohli A, Banerjee KK. Pattern of injuries in fatal falls from buildings. Med Sci Law 2006;46:335-41. CrossRef

9. Payne SR, Waller JA, Skelly JM, Gamelli RL. Injuries during woodworking, home repairs, and construction. J Trauma 1990;30:276-80. CrossRef

10. Goren S, Subasi M, Týrasci Y, Gurkan F. Fatal falls from heights in and around Diyarbakir, Turkey. Forensic Sci Int 2003;137:37-40. CrossRef

11. Committee on Injury and Poison Prevention. American 
Academy of Pediatrics: Falls from heights: windows, roofs, and balconies. Pediatrics 2001;107:1188-91. CrossRef

12. Lapostolle F, Borron SW, Gere C, Dallemagne F, Beruben A, Lapandry C, et al. Victims of fall from height. Study of 287 patients and determination of clinical prognostic factors. [Article in French] Ann Fr Anesth Reanim 2004;23:689-93.

13. Sawyer JR, Flynn JM, Dormans JP, Catalano J, Drummond DS. Fracture patterns in children and young adults who fall from significant heights. J Pediatr Orthop 2000;20:197-202.

14. Agalar F, Cakmakci M, Sayek I. Factors effecting mortality in urban vertical free falls: evaluation of 180 cases. Int Surg 1999;84:271-4.

15. Goodacre S, Than M, Goyder EC, Joseph AP. Can the distance fallen predict serious injury after a fall from a height? J
Trauma 1999;46:1055-8. CrossRef

16. Faergemann C, Larsen LB. Non-occupational ladder and scaffold fall injuries. Accid Anal Prev 2000;32:745-50. CrossRef

17. Partridge RA, Virk AS, Antosia RE. Causes and patterns of injury from ladder falls. Acad Emerg Med 1998;5:31-4. CrossRef

18. Kent A, Pearce A. Review of morbidity and mortality associated with falls from heights among patients presenting to a major trauma centre. Emerg Med Australas 2006;18:2330. CrossRef

19. Tsipouras S, Hendrie JM, Silvapulle MJ. Ladders: accidents waiting to happen. Med J Aust 2001;174:516-9.

20. O’Sullivan J, Wakai A, O’Sullivan R, Luke C, Cusack S. Ladder fall injuries: patterns and cost of morbidity. Injury 2004;35:429-31. CrossRef 